\title{
Entomocidal properties of Monodora myristica (Dunal, 1831) and Conyza sumatrensis (Retzius, 1742-1821) extracts: Studies on two dipterous insect pests Anopheles gambiae (Giles, 1902) and Culex quinquefasciatus (Say, 1823)
}

\section{Kayode David Ileke}

Department of Biology. School of Science. Federal University of Technology. P. M. B. 704. Akure. Ondo State. Nigeria. Email: kdileke@futa.edu.ng.

\begin{abstract}
Anopheles gambiae (Giles, 1902) and Culex quinquefasciatus (Say, 1832) mosquitoes are the main vectors of human malaria and lymphatic filariasis, respectively. This study aims to analyze the larvicidal, pupicidal and adulticidal properties of Monodora myristica (Dunal, 1831) and Conyza sumatrensis (Retzius, 1742-1821) extracts against An. gambiae and $C x$. quinquefasciatus. The experiment was conducted in the laboratory at ambient temperature of $28{ }^{\circ} \mathrm{C} \pm 2{ }^{\circ} \mathrm{C}$ and $75 \% \pm$ $5 \%$ relative humidity. The results showed that $M$. myristica and $C$. sumatrensis extracts significantly affect all stages of An. gambiae and $C x$. quinquefasciatus tested. The mosquitocidal toxicity of the two plant extracts is dosage dependent. Antilarval activity of M. myristica at rate $500 \mathrm{mg} / \mathrm{L}$ and 1,000 mg/L caused $100 \%$ mortality of An. gambiae larvae while it evoked $80 \%$ and $100 \%$ mortality of $C x$. quinquefasciatus larvae. The same trend of results were also obtained on the anti-pupal and adulticidal toxicity of M. myristica and C. sumatrensis extracts. As larvicides, pupicides and adulticides, the $\mathrm{LC}_{50} \mathrm{~S}$ and $\mathrm{LC}_{90} \mathrm{~S}$, after $24 \mathrm{~h}$ varied across plant extracts and mosquito species. C. sumatrensis attained $\mathrm{LC}_{50}$ and $\mathrm{LC}_{90}$ at higher concentration than M. myristica. On An. gambiae larvae, the $\mathrm{LC}_{50} \mathrm{~S}$ after $24 \mathrm{~h}$, varied from $86.95 \mathrm{mg} / \mathrm{L} \mathrm{(M.} \mathrm{myristica)} \mathrm{to} 131.73 \mathrm{mg} / \mathrm{L}$ (C. sumatrensis). Similarly, the $\mathrm{LC}_{90} \mathrm{~S}$ after $24 \mathrm{~h}$ on An. gambiae larvae, varied from $278.39 \mathrm{mg} / \mathrm{L}$ (M. myristica) to $131.73 \mathrm{mg} / \mathrm{L}$ (C. sumatrensis). For $C x$. quinquefasciatus larvae, the $\mathrm{LC}_{50} \mathrm{~S}$ after $24 \mathrm{~h}$, varied from $391.41 \mathrm{mg} / \mathrm{L}$ (M. myristica) to $898.20 \mathrm{mg} / \mathrm{L}$ (C. sumatrensis). The seed extract of $M$. myristica exerted the best pupicidal activity among the two tested extracts with $\mathrm{LC}_{50}$ and $\mathrm{LC}_{90}$ values of $140.61 \mathrm{mg} / \mathrm{L}$ and $520.35 \mathrm{mg} / \mathrm{L}$ on An. gambiae, respectively, followed by leaf of $C$. sumatrensis with $\mathrm{LC}_{50}$ and $\mathrm{LC}^{90}$ values of $157.59 \mathrm{mg} / \mathrm{L}$ and $781.86 \mathrm{mg} / \mathrm{L}$ on An. gambiae, respectively. More concentrations were require to achieve $50 \%$ and $90 \%$ death of $C x$. quinquefasciatus pupae. On adulticidal activity, seed of $M$. myristica exerted $\mathrm{LC}_{50}$ and $\mathrm{LC}_{90}$ values of $122.79 \mathrm{mg} / \mathrm{L}$ and $502.99 \mathrm{mg} / \mathrm{L}$ on An. gambiae, respectively, followed by leaf of $C$. sumatrensis with $\mathrm{LC}_{50}$ and
\end{abstract}

Received

August 11, 2018

Accepted

August 30, 2018

Released

August 31, 2018

Full Text Article

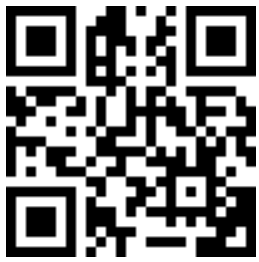

๑ $0000-0002-3106-4328$ Kayode David Ileke 
LC 90 values of $215.05 \mathrm{mg} / \mathrm{L}$ and $981.25 \mathrm{mg} / \mathrm{L}$ on $A n$. gambiae, respectively. More concentrations were require to achieve $50 \%$ and $90 \%$ death of $C x$. quinquefasciatus adults. The two tested plants can be integrated into pest management programmes to combat human malaria and lymphatic filariasis vectors breeding site in Nigeria. I recommend formulation of $M$. myristica seeds which have the lowest $\mathrm{LC}_{50}$ and $\mathrm{LC}_{90}$ after $24 \mathrm{~h}$ of exposure for field evaluation.

Keywords: Entomocidal; Monodora myristica; Conyza sumatrensis; Anopheles gambiae; Culex quinquefasciatus.

\section{Introduction}

The dipterans are the most important orders of hexapods with veterinary and medical importance, which can transmit many pathogenic parasites causing diseases such as malaria and filariasis among the rural dwellers in the world (Sanei-Dehkordi et al., 2018). Anopheles and Culex mosquitoes are most dangerous vectors commonly find in tropical region (Okorie et al., 2014). About $40 \%$ of the world population live in this region ( $\mathrm{Pal}$ et al., 2014) and this shows how preventive measurement is essential in this area. Despite the efforts made by World Health Organization and researchers over the past decades to decline the mortality rate of malaria and lymphatic filariasis all over the world, malaria disease are still household illness in the tropical regions of the world (Ileke et al., 2017; Vatandoost et al., 2018). Human malaria is the most important vector-borne disease caused by Plasmodium species transmitted by anopheline mosquitoes. About 212 million peoples were suffering from malaria with 429,000 deaths recorded worldwide (WHO, 2016). Culex species is the most medically important vectors of human pathogens causing etiologic agents of different forms of encephalitis, Rift valley fever and lymphatic filariasis that are still predominant in the tropical region (Vatandoost et al., 2018). Immediate intervention in the control of these vectors in the rural area where the breeding of mosquitoes appeared permanent or semi-permanent as a result of ignorance of the vectors on the part of rural dwellers.

Vectors control programme have been intensified by medical entomologists and parasitologists throughout the world with the use of botanicals in lieu of synthetic chemical insecticides which are toxic to untargeted organisms and natural enemies as well as high cost of purchase in the management of malaria and lymphatic filariasis vectors (WHO, 2013; Vatandoost et al., 2018).

Monodora myristica is a tropical tree of the Family Annonaceae. The plant is about $35 \mathrm{~m}$ high and $2 \mathrm{~m}$ in diameter. It has a clear trunk and branches horizontally (Fournier et al., 1999). The leaves are alternately arranged and drooping with the leaf blade being elliptical, oblong or broadest towards the apex and tapering to the stalk (Weiss, 2002). It is a flowering plant with the seeds containing $5 \%-9 \%$ of a colourless essential oil (Weiss, 2002). The plant is used as stimulants, stomachic, for headaches, sores and also as insect repellent. The seeds are also made into necklaces (Weiss, 2002). Previous studies have shown that its polar extracts possess insecticidal properties against cowpea beetle, Callosobruchus maculatus (Okosun and Adedire, 2010; 2017). It also possess ant-larval against Aedes albopictus (Tankeu et al., 2016)

Conyza sumatrensis is an annual, biennial or perennial herbaceous plant that belong to Family Asteraceae. The genus Conyza consists of about 80-100 
described species (Beentje, 2002; Chai et al., 2008). The oil of $C$. sumatrensis have antimicrobial and antifungal effects (Deans et al., 1992). Liu et al. (2012) reported the antifugi activity of C. sumatrensis against Phoma macrostoma.

In view of the current trend of developing plant based insecticides as a substitute to synthetic chemical insecticides, this study was undertaken to evaluate the larvicidal, pupicidal and adulticidal properties of $M$. myristica (Dunal, 1831) and C. sumatrensis (Retzius, 1742-1821) extracts against $A n$. gambiae (Giles, 1902) and Cx. quinquefasciatus (Say, 1823) mosquitoes, a major vector of malaria and lymphatic filariasis, respectively.

\section{Materials and methods}

\section{Collection and rearing of larva, pupa and adult mosquitoes \\ Mosquito baits, consisting of} shallow containers with a large surface area was established under a partial shade in an open field by filling the white bucket with rain water. $10 \mathrm{~g}$ of yeast (Bakers' yeast) were sprinkled on the surface of the water to serves as source of foods for the nourishment of larvae. Wild mosquitoes were allowed to freely visit the baits and to lay eggs. This was monitored for 4-6 days for the development of the egg and first larva instar. These larvae were taken into the laboratory for identification into species levels (Gillies and De Meillon, 1968). The An. gambiae and $C x$. quinquefasciatus larvae were separated from the mixed culture and transferred into another plastic container containing rain water to get a pure culture of each of the two dipterous insects. Some of the larvae were used for the larvicidal tests. The $A n$. gambiae and $C x$. quinquefasciatus larvae were further nurtured to pupae for 4-6 days for pupicidal tests.

Adult mosquitoes that emerged were fed with $10 \%$ sucrose solution and periodically fed with blood of 5-7 weeks restrained chick (Afolabi et al., 2018). The reared mosquitoes were maintained at $28{ }^{\circ} \mathrm{C} \pm 2{ }^{\circ} \mathrm{C}$ and $75 \% \pm 5 \%$ relative humidity, $12 \mathrm{~h}$ light followed by $12 \mathrm{~h}$ dark photoperiod.

\section{Collection of plant materials and extraction}

The plants evaluated in this work were M. myristica seeds and C. sumatrensis leaves. The fully developed leaves of $C$. sumatrensis, free of insecticides were obtained in fresh form from the premise of Strategic Grains Reserve Oda Road, Akure, Ondo State. The seeds of $M$. myristica were collected from Erekesan Market, Akure, Ondo State. They were taken to the Biology Department, Federal University of Technology, Akure, Ondo State, for authentication by plant taxonomist. The leaves of $C$. sumatrensis were washed with distilled water, shade dried, cut into small pieces and air dried for 14 days in the laboratory. The seeds of $M$. myristica were also air dried for 21 days before pulverized into fine powders using an industrial electric pulverizing machine at the Department of Animal Production and Health Laboratory of the Federal University of Technology Akure. The powders were further sieved to pass through $1 \mathrm{~mm}^{2}$ perforations and kept in an air-tight plastic containers for storage before use at ambient temperature $28{ }^{\circ} \mathrm{C}$ $\pm 2{ }^{\circ} \mathrm{C}$.

About $300 \mathrm{~g}$ of M. myristica and $C$. sumatrensis powders were soaked separately in an extraction bottle containing $600 \mathrm{~mL}$ of absolute methanol for $72 \mathrm{~h}$. The mixture was stirred occasionally with a glass rod and extraction was terminated after $72 \mathrm{~h}$. Filtration was carried out using a double layer of Whatman No. 1 filter papers and solvent evaporated using a rotary evaporator at $30{ }^{\circ} \mathrm{C}$ to $40{ }^{\circ} \mathrm{C}$ with rotary speed of 3 to $6 \mathrm{rpm}$ for $8 \mathrm{~h}$ (Udo, 2011). The resulting extracts was air dried in order to remove traces of solvent. The extracts were kept in labeled plastic bottles till when needed. 

solution

Preparation of standard stock

Standard stock solutions were prepared by dissolving $2 \mathrm{~g}$ of the crude extracts in $1 \mathrm{~L}$ of water. From these stock solutions, different concentrations of $62.5 \mathrm{mg} / \mathrm{L}, 125 \mathrm{mg} / \mathrm{L}, 250 \mathrm{mg} / \mathrm{L}, 500$ $\mathrm{mg} / \mathrm{L}$ and 1,000 $\mathrm{mg} / \mathrm{L}$ were prepared and these aqueous solutions were used for the various experiment.

Larvicidal, pupicidal and and adulticidal bioassay

$100 \mathrm{~mm}$ of aqueous solutions of the various plant extracts at various concentrations of $62.5 \mathrm{mg} / \mathrm{L}, 125 \mathrm{mg} / \mathrm{L}$, $250 \mathrm{mg} / \mathrm{L}, 500 \mathrm{mg} / \mathrm{L}$ and $1,000 \mathrm{mg} / \mathrm{L}$ were each put in a labelled transparent bowl. 25 days old larvae of Anopheles and Culex mosquitoes were introduced separately into the various plant extracts. They were replicated four times and water was used as control. The number of dead larvae were counted and recorded accordingly after $24 \mathrm{~h}$ of treatment. Dead larvae were those incapable of rising to the surface or without the characteristic diving reaction when the water was disturbed (WHO, 2006; 2009).

$$
\% \text { Larval Mortality }=\frac{\text { Number of dead larvae }}{\text { Number of larvae introduced }} \times \frac{100}{1}
$$

Similar experiment as described above was carried out for An. gambiae and $C x$. quinquefasciatus pupae. 22 days old pupae of An. gambiae and CX. quinquefasciatus were introduced separately into the various $M$. myristica and $C$. sumatrensis concentrations. They were replicated four times and water was used as control. The number of dead pupae were counted and recorded accordingly after $24 \mathrm{~h}$ of treatment.

20 An. gambiae and $C x$. quinquefasciatus adults were introduced into separate round bottom conical flask that contain suspended filter papers soaked with $62.5 \mathrm{mg} / \mathrm{L}, 125 \mathrm{mg} / \mathrm{L}, 250$ $\mathrm{mg} / \mathrm{L}, 500 \mathrm{mg} / \mathrm{L}$ and $1,000 \mathrm{mg} / \mathrm{L} M$. myristica and $C$. sumatrensis extracts separately for adult bioassay. They were replicated four times and water was used as control. Mortality of adult insect was accessed after $24 \mathrm{~h}$ of exposure.

\section{Statistical analysis of data}

Percentage larvae, pupae and adults mortalities were estimated and corrected according to Abbott's Formula (Abott, 1925). The log-Probit model analysis (Finney, 1971) was done to the data recorded in the larvicidal, pupicidal and adulticidal bioassay to assess the $50 \%$ and $90 \%$ lethal concentrations.

\section{Results}

Toxicity of Plant Extracts on An. gambiae and $C x$. quinquefasciatus Larvae

Mortalities resulted from exposing the An. gambiae and $C x$. quinquefasciatus larvae to different concentrations of $M$. myristica and $C$. sumatrensis extracts is presented in Table 1. Mortalities of larval stage of the tested mosquitoes, An. gambiae and $C x$. quinquefasciatus occurred in a dosagedependent manner. 
Table 1. Toxicity of plant extracts on larvae An. gambiae and Cx. quinquefasciatus after $24 \mathrm{~h}$ of exposure.

\begin{tabular}{|c|c|c|c|c|c|c|}
\hline \multirow{2}{*}{ Mosquitoes } & \multirow{2}{*}{ Plant extracts } & \multicolumn{5}{|c|}{ Concentration (mg/L) } \\
\hline & & 62.5 & 125.0 & 250.0 & 500.0 & $1,000.0$ \\
\hline \multirow[t]{3}{*}{ An. gambiae } & M. myristica & $42.50 \pm 4.79^{c}$ & $57.50 \pm 2.50^{c}$ & $85.00 \pm 2.89^{c}$ & $100.00 \pm 0.0^{c}$ & $100.00 \pm 0.0^{b}$ \\
\hline & C. sumatrensis & $32.50 \pm 2.50^{b}$ & $45.00 \pm 2.89^{b}$ & $67.50 \pm 2.50^{\mathrm{b}}$ & $80.00 \pm 2.75^{b}$ & $100.00 \pm 0.0^{b}$ \\
\hline & Untreated & $0.00 \pm 0.00^{\mathrm{a}}$ & $0.00 \pm 0.00^{\mathrm{a}}$ & $0.00 \pm 0.00^{\mathrm{a}}$ & $0.00 \pm 0.00^{\mathrm{a}}$ & $0.00 \pm 0.00^{\mathrm{a}}$ \\
\hline \multirow[t]{3}{*}{ Cx. quinquefasciatus } & M. myristica & $35.00 \pm 2.89^{c}$ & $52.50 \pm 2.50^{c}$ & $80.00 \pm 2.75^{c}$ & $92.50 \pm 2.50^{c}$ & $100.00 \pm 0.0^{b}$ \\
\hline & C. sumatrensis & $20.00 \pm 2.75^{b}$ & $35.00 \pm 2.89^{b}$ & $55.00 \pm 2.89^{\mathrm{b}}$ & $72.50 \pm 2.50^{\mathrm{b}}$ & $92.50 \pm 2.50^{b}$ \\
\hline & Untreated & $0.00 \pm 0.00^{\mathrm{a}}$ & $0.00 \pm 0.00^{\mathrm{a}}$ & $0.00 \pm 0.00^{\mathrm{a}}$ & $0.00 \pm 0.00^{\mathrm{a}}$ & $0.00 \pm 0.00^{\mathrm{a}}$ \\
\hline
\end{tabular}

All values are means of four replicate followed by \pm Standard error of the mean. Mean followed by the same letters, superscript at the end of each value, down the column are not significantly different $(p>0.05)$ from one another using Tukey's Test.

There was significant differences $(p<0.05)$ in toxicity level of the two plant extracts on An. gambiae and $C x$. quinquefasciatus larvae at concentration $62 \mathrm{mg} / \mathrm{L}, 125 \mathrm{mg} / \mathrm{L}, 250$ $\mathrm{mg} / \mathrm{L}$ and $500 \mathrm{mg} / \mathrm{L}$. African nutmeg, M. myristica caused $42.5 \%, 57.5 \%, 85 \%$, $100 \%$ and $100 \%$ mortality of An. gambiae larvae at rates $62 \mathrm{mg} / \mathrm{L}, 125$ $\mathrm{mg} / \mathrm{L}, 250 \mathrm{mg} / \mathrm{L}, 500 \mathrm{mg} / \mathrm{L}$ and 1,000 $\mathrm{mg} / \mathrm{L}$, respectively.

C. sumatrensis extract at rates 62 $\mathrm{mg} / \mathrm{L}, 125 \mathrm{mg} / \mathrm{L}, 250 \mathrm{mg} / \mathrm{L}, 500 \mathrm{mg} / \mathrm{L}$ and $1,000 \mathrm{mg} / \mathrm{L}$ evoked $32.5 \%, 45 \%$, $67.5 \%, 80 \%$ and $100 \%$ mortality of An. gambiae larvae, respectively.

African nutmeg, $M$. myristica caused $35 \%, 52.5 \%, 80 \%, 92.5 \%$ and $100 \%$ mortality of $C x$. quinquefasciatus larvae at rates $62 \mathrm{mg} / \mathrm{L}, 125 \mathrm{mg} / \mathrm{L}, 250$ $\mathrm{mg} / \mathrm{L}, \quad 500 \mathrm{mg} / \mathrm{L}$ and $1,000 \mathrm{mg} / \mathrm{L}$, respectively. C. sumatrensis extract at rates $62 \mathrm{mg} / \mathrm{L}, 125 \mathrm{mg} / \mathrm{L}, 250 \mathrm{mg} / \mathrm{L}, 500$ $\mathrm{mg} / \mathrm{L}$ and $1,000 \mathrm{mg} / \mathrm{L}$ evoked 20\%, 35\%, $55 \%, 72.5 \%$ and $92.5 \%$ mortality of CX. quinquefasciatus, respectively.

At concentration $1,000 \mathrm{mg} / \mathrm{L}$, both plant extracts had $100 \%$ mortality on An. gambiae an effect that was not significantly different $(\mathrm{p}>0.05)$ from mortality of $C x$. quinquefasciatus larvae. Based on the results obtained, M. myristica caused more mortality of
An. gambiae than Cx. quinquefasciatus larvae.

Toxicity of plant extracts on An. gambiae and $C x$. quinquefasciatus pupae

Figure 1 showed the toxicity of M. myristica and C. sumatrensis extracts on An. gambiae and Cx. quinquefasciatus pupae. There was significant differences $(p<0.05)$ in toxicity level of the $M$. myristica and $C$. sumatrensis extracts on An. gambiae and Cx. quinquefasciatus pupae at concentration $62 \mathrm{mg} / \mathrm{L}, 125$ $\mathrm{mg} / \mathrm{L}, 250 \mathrm{mg} / \mathrm{L}, 500 \mathrm{mg} / \mathrm{L}$ and 1,000 $\mathrm{mg} /$ L. M. myristica evoked 35\%, 50\%, $70 \%, 87.5 \%$ and $100 \%$ mortality of An. gambiae pupae at rates $62 \mathrm{mg} / \mathrm{L}, 125$ $\mathrm{mg} / \mathrm{L}, 250 \mathrm{mg} / \mathrm{L}, 500 \mathrm{mg} / \mathrm{L}$ and 1,000 $\mathrm{mg} / \mathrm{L}$, respectively.

C. sumatrensis extract at rates 62 $\mathrm{mg} / \mathrm{L}, 125 \mathrm{mg} / \mathrm{L}, 250 \mathrm{mg} / \mathrm{L}, 500 \mathrm{mg} / \mathrm{L}$ and $1,000 \mathrm{mg} / \mathrm{L}$ caused $25 \%, 40 \%$, $62.5 \%, 85 \%$ and $92.5 \%$ mortality of $A n$. gambiae pupae, respectively. M. myristica evoked 30\%, 45\%, 65\%, 80\% and 95\% mortality of $C x$. quinquefasciatus pupae at rates $62 \mathrm{mg} / \mathrm{L}, 125 \mathrm{mg} / \mathrm{L}, 250 \mathrm{mg} / \mathrm{L}, 500$ $\mathrm{mg} / \mathrm{L}$ and $1,000 \mathrm{mg} / \mathrm{L}$, respectively.

C. sumatrensis extract at rates 62 $\mathrm{mg} / \mathrm{L}, 125 \mathrm{mg} / \mathrm{L}, 250 \mathrm{mg} / \mathrm{L}, 500 \mathrm{mg} / \mathrm{L}$ and $1,000 \mathrm{mg} / \mathrm{L}$ caused $20 \%, 35 \%, 60 \%$, $70 \%$ and $90 \%$ mortality of $C x$. quinquefasciatus pupae, respectively. 


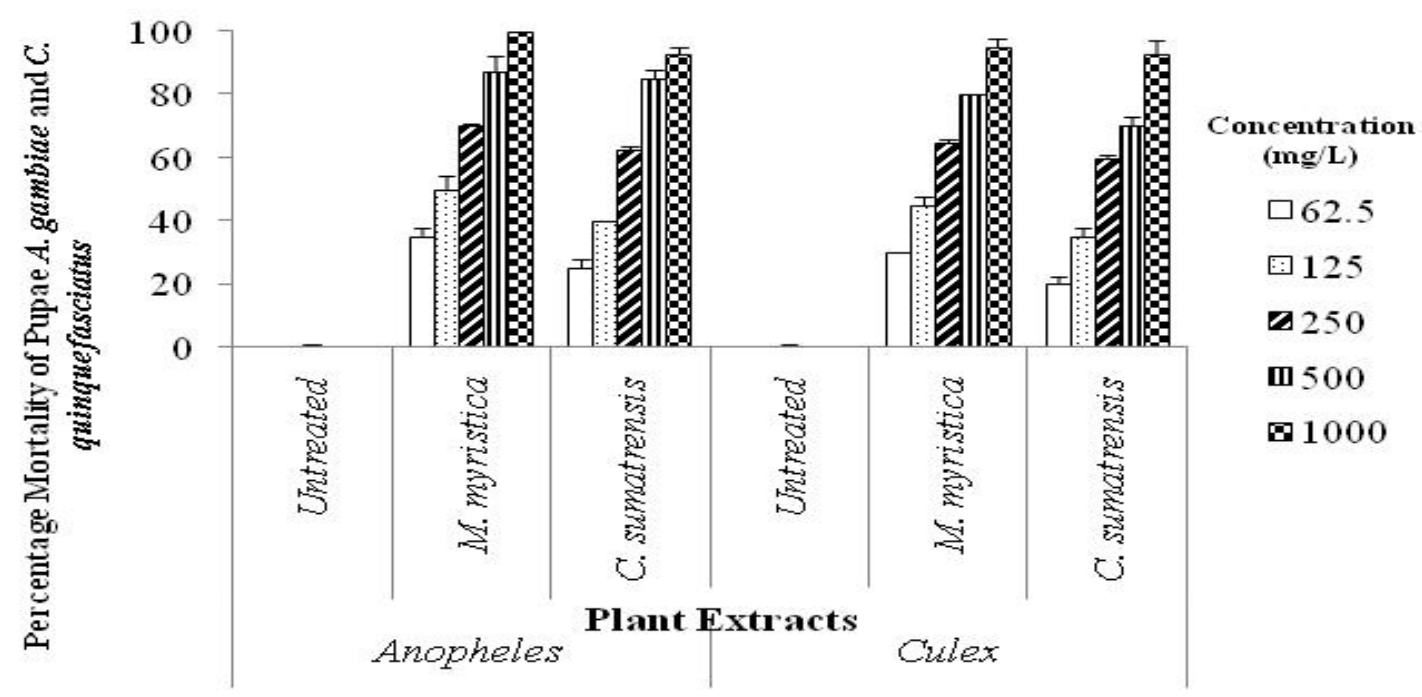

Figure 1: Toxicity of Plant Extracts on Pupae Anopheles gambiae and Culex quinquefasciatus mosquitoes after 24 hours of exposure

Both M. myristica and $C$. sumatrensis extracts had 100\% mortality on An. gambiae pupae an effect that was not significantly different $(\mathrm{p}>0.05)$ from mortality of $C x$. quinquefasciatus pupae. M. myristica caused more mortality of $A n$. gambiae than $C x$. quinquefasciatus pupae.

Fumigant toxicity of plant extracts on An. gambiae and $C x$. quinquefasciatus adults

Figure 2 showed the fumigant toxicity of M. myristica and C. sumatrensis extracts on An. gambiae and CX. quinquefasciatus adults after $24 \mathrm{~h}$ of exposure.

M. myristia extract caused more mortality of adults An. gambiae than $C x$.quinquefasciatus after $24 \mathrm{~h}$ of exposure. There was significant different $(p<0.05)$ in the effects of $M$. myristica and $C$. sumatrensis extracts on adults $A n$. gambiae and $C x$. quinquefasciatus at rates $62 \mathrm{mg} / \mathrm{L}, 125 \mathrm{mg} / \mathrm{L}, 250 \mathrm{mg} / \mathrm{L}$ and 500
mg/L. M. myristica caused 32.5\%, 47.5\%, $67.5 \%, 90 \%$ and $100 \%$ mortality of An. gambiae adults at rates $62 \mathrm{mg} / \mathrm{L}, 125$ $\mathrm{mg} / \mathrm{L}, 250 \mathrm{mg} / \mathrm{L}, 500 \mathrm{mg} / \mathrm{L}$ and 1,000 $\mathrm{mg} / \mathrm{L}$, respectively.

Cx sumatrensis extract at rates 62 $\mathrm{mg} / \mathrm{L}, 125 \mathrm{mg} / \mathrm{L}, 250 \mathrm{mg} / \mathrm{L}, 500 \mathrm{mg} / \mathrm{L}$ and $1,000 \mathrm{mg} / \mathrm{L}$ evoked 20\%, 27.5\%, $50 \%, 77.5 \%$ and $92.5 \%$ mortality of An.gambiae adults respectively. M. myristica extract caused 30\%, 45\%, $62.5 \%, 85 \%$ and $97.5 \%$ mortality of CX. quinquefasciatus adults at rates $62 \mathrm{mg} / \mathrm{L}, 125 \mathrm{mg} / \mathrm{L}, 250 \mathrm{mg} / \mathrm{L}, 500 \mathrm{mg} / \mathrm{L}$ and $\quad 1000 \mathrm{mg} / \mathrm{L} \quad$ respectively. C. sumatrensis extract at rates $62 \mathrm{mg} / \mathrm{L}$, $125 \mathrm{mg} / \mathrm{L}, \quad 250 \mathrm{mg} / \mathrm{L}, \quad 500 \mathrm{mg} / \mathrm{L}$ and $1000 \mathrm{mg} / \mathrm{L}$ caused $15 \%, 22.5 \%, 45 \%$, $72.5 \%$ and $85 \%$ mortality of Cx quinquefasciatus adults respectively. $M$. myristica extract had the highest percentage of mortality of adults $A n$. gambiae and $C x$. quinquefasciatus at all tested concentrations. 


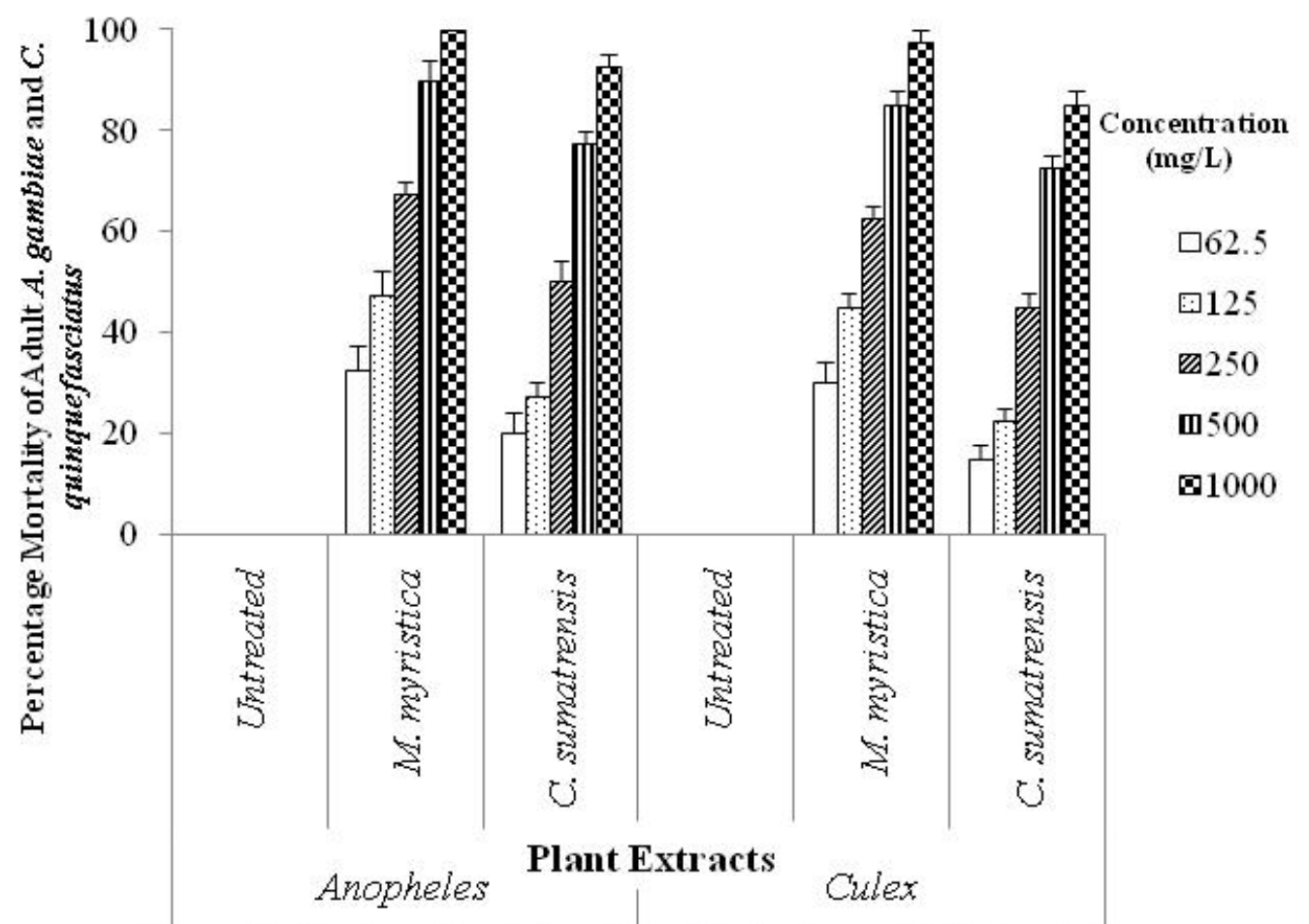

Figure 2: Fumigant Toxicity of Plant Extracts on Adult Anopheles gambiae and Culex quinquefasciatus mosquitoes after 24 hours of exposure.

\section{$\mathrm{LC}_{50}$ and $\mathrm{LC}_{90}$ values calculated for the tested plant extracts}

$\mathrm{LC}_{50}$ and $\mathrm{LC}_{90}$ of the M. myristica

and C.sumatrensis extracts on An. gambiae and Cx. quinquefasciatus larvae, pupae and adults is presented in Table 2 and 3.

The $\mathrm{LC}_{50}$ of $M$. myristica extract was $86.95 \mathrm{mg} / \mathrm{L}$ while C. sumatrensis extract was $131.73 \mathrm{mg} / \mathrm{L}$ for An. gambiae larvae.

The concentration of M. myristica and $C$. sumatrensis extracts to cause $50 \%$ death of $C x$. quinquefasciatus larvae were $103.83 \mathrm{mg} / \mathrm{L}$ and $189.48 \mathrm{mg} / \mathrm{L}$, respectively. The $\mathrm{LC}_{90}$ of $M$. myristica extract was $278.39 \mathrm{mg} / \mathrm{L}$ while C. sumatrensis extract was $648.98 \mathrm{mg} / \mathrm{L}$ for An. gambiae larvae. The concentration of $M$. myristica and C. sumatrensis extracts to cause $90 \%$ death of $C X$. quinquefasciatus larvae were
$391.41 \mathrm{mg} / \mathrm{L}$ and $898.20 \mathrm{mg} / \mathrm{L}$, respectively.

The concentration of M. myristica and $C$. sumatrensis extracts required to evoke $50 \%$ death of An. gambiae pupae were $115.22 \mathrm{mg} / \mathrm{L}$ and $157.59 \mathrm{mg} / \mathrm{L}$, respectively. The $\mathrm{LC}_{50}$ of $M$. myristica extract was $140.61 \mathrm{mg} / \mathrm{L}$ while C. sumatrensis extract was $197.49 \mathrm{mg} / \mathrm{L}$ for $C x$. quinquefasciatus pupae.

The concentration of $M$. myristica and $C$. sumatrensis extracts required to evoke $90 \%$ death of An. gambiae pupae were $520.35 \mathrm{mg} / \mathrm{L}$ and $781.86 \mathrm{mg} / \mathrm{L}$, respectively. The $\mathrm{LC}_{90}$ of $M$. myristica and C. sumatrensis extracts were 803.78 $\mathrm{mg} / \mathrm{L}$ and $1,051.47 \mathrm{mg} / \mathrm{L}$ for Cx. quinquefasciatus pupae, respectively.

The adult An. gambiae required $122.79 \mathrm{mg} / \mathrm{L}$ and $215.05 \mathrm{mg} / \mathrm{L}$ of $M$. myristica and $C$. sumatrensis extracts to cause $50 \%$ death. The $\mathrm{LC}_{50}$ of $M$. myristica and C. sumatrensis extracts 
were $138.46 \mathrm{mg} / \mathrm{L}$ and $270.52 \mathrm{mg} / \mathrm{L}$ for $C x$. quinquefasciatus adults, respectively.

The concentration of $M$. myristica and $C$. sumatrensis extracts required to evoke $90 \%$ death of An. gambiae adults were $502.99 \mathrm{mg} / \mathrm{L}$ and $981.25 \mathrm{mg} / \mathrm{L}$, respectively. The $\mathrm{LC}_{90}$ of $M$. myristica and C. sumatrensis extracts were 664.46 $\mathrm{mg} / \mathrm{L}$ and $1,330.48 \mathrm{mg} / \mathrm{L}$ for $C x$. quinquefasciatus adults, respectively.

Table 2. $\mathrm{LC}_{50}$ of $M$. myristica and $C$. sumatrensis extracts on An. gambiae and Cx. quinquefasciatus larvae, pupae and adults.

\begin{tabular}{llcc}
\hline \multirow{2}{*}{$\begin{array}{c}\text { Mosquito } \\
\text { Developmental Stages }\end{array}$} & \multicolumn{2}{c}{ Mosquitoes } & \multicolumn{2}{c}{ LC $\mathbf{5 0}_{\mathbf{5}}$ (lower-upper limit) of plant extracts } \\
\cline { 3 - 4 } & & M. myristica & C. sumatrensis \\
\hline Larvae & An. gambiae & 86.92 & 131.73 \\
& & $(43.57-125.59)$ & $(60.47-211.05)$ \\
& CX. quinquefasciatus & 103.83 & 189.48 \\
Pupae & $(87.04-120.56)$ & $(110.93-297.28)$ \\
& An. gambiae & 115.22 & 157.59 \\
& & $(66.57-165.0)$ & $(132.45-184.29)$ \\
Adults & CX. quinquefasciatus & 140.61 & 197.49 \\
& \multirow{2}{*}{ An. gambiae } & $(115.32-166.89)$ & $(166.98-231.43)$ \\
& \multirow{2}{*}{ Cx. quinquefasciatus } & 122.79 & 215.05 \\
& & $(72.59-176.03)$ & $(184.95-249.13)$ \\
& & 138.46 & 270.52 \\
\end{tabular}

Table 3. $\mathrm{LC}_{90}$ of M. myristica and C. sumatrensis extracts on An. gambiae and Cx. quinquefasciatus larvae, pupae and adults;

\begin{tabular}{llcc}
\hline \multirow{2}{*}{$\begin{array}{c}\text { Mosquito } \\
\text { Developmental Stages }\end{array}$} & \multicolumn{1}{c}{ Mosquitoes } & \multicolumn{2}{c}{ LC } \\
\cline { 3 - 4 } & An. gambiae & M. myristica & C. sumatrensis \\
\hline Larvae & $(184.7-758.22)$ & 648.98 \\
& & 391.41 & $(362.21-935.75)$ \\
& Cx. quinquefasciatus & $(323.07-503.02)$ & $(500.85-1295.55)$ \\
Pupae & An. gambiae & 520.35 & 781.86 \\
& & $(332.17-708.3)$ & $(612.60-951.12)$ \\
& Cx. quinquefasciatus & 803.78 & $1,051.47$ \\
Adults & $(616.17-991.39)$ & $(800.98-1,522.40)$ \\
& An. gambiae & 502.99 & 981.25 \\
& & $(321.24-684.74)$ & $(767.11-1,195.39)$ \\
& Cx. quinquefasciatus & 664.46 & $1,330.48$ \\
& & $(525.47-910.24)$ & $(1,009.59-1,651.37)$
\end{tabular}

\section{Discussion}

The utilization of botanicals in vectors management is gaining interest as results of the hazard associated with synthetic chemical insecticides such as toxic wastes hazard and toxicity on nontargeted organism's couple with high 
cost of purchase. Exploitation of low cost materials, such as agricultural wastes (cocoa pod, orange peel, cowpea pod), used in rural settlement against vectors of malaria and lymphatic filariasis may lead to promising control strategies in in developing countries (Sukumar et al., 1991; Tankeu et al., 2016). Many tropical plants have been reported to contain bioactive compound against stored product pests and vector of malaria (Adedire and Ajayi, 1996; Adedire and Lajide, 1999; Shaalan et al., 200; Adedire, 2003; Adedire et al., 2011, Akinkurolere et al., 2011, Ileke and Ogungbite, 2015; Ileke et al., 2015; 2016; Awosolu et al., 2018). Presently, larvicidal, pupiidal and adulticidal properties of $M$. myristica seeds and $C$. sumatrensis leaves extracts on two dipterous insect pests. An. gambiae and $C x$. quinquefasciatus has been investigated.

According to the results of this study, the M. myristica and C. sumatrensis extracts showed insecticidal effect on all stages of An. gambiae and $C x$.quinquefasciatus tested. The mosquitocidal toxicity is dosage dependent; the higher the concentration, the higher the mortality rate of the vectors developmental stages. Anti-larval activity of $M$. myristica at rate $500 \mathrm{mg} / \mathrm{L}$ and $1,000 \mathrm{mg} / \mathrm{L}$ caused $100 \%$ mortality of An. gambiae larvae while it evoked $80 \%$ and $100 \%$ mortality of Cx. quinquefasciatus larvae. The same trend of results were also obtained on the anti-pupal and aduticidal toxicity of $M$. myristica and $C$. sumatrensis extracts the two dipterous insects. The insecticidal potential of $M$. myristica extracted with five different solvents against cowpea bruchid, Callosobruchus maculatus have been reported by Okosun and Adedire (2010; 2017). Adedire (2003) made similar observation on the toxicity of Nutmeg in the control of Callosobruchus maculatus. The insecticidal activity of the $M$. myristica extract against two dipterous insects in this study may be due to the presence of various bioactive compounds such as alkaloids, terpenoids, phenolics, tannins and flavonoids (Vindhya et al., 2014; Tankeu et al., 2016). Emeasor et al. (2005) ascribed the effectiveness of $M$. fragrans to give a long term protection to cowpea seeds as result of active components such as phellandrene, $\mathrm{p}$ cymene and limonene, which possess pesticidal properties.

Conyza sumatrensis is an annual, biennial or perennial herbaceous plant that belong to family Asteraceae. Exposure of An. gambiae and Cx. quinquefasciatus larvae, pupae and adults to a range of concentrations (62.5 $\mathrm{mg} / \mathrm{L}-1,000 \mathrm{mg} / \mathrm{L}$ ) caused mortalities ranged between $20 \%-100 \%$. The toxicity of $C$ sumatrensis to all the developmental stages of $C X$. quinquefasciatus tested may be due to presence of limonene content in the essential extract as suggested by Sfara et al. (2009) and Kassir et al. (1989). African nutmeg, M. myristica extract had significant mosquitocidal activity than $C$. sumatrensis extract to all stages of An. gambiae and $C x$. quinquefasciatus investigated. Kehail et al. (2017) reported $100 \%$ and $60 \%$ mortality of Anopheles and Culex mosquitoes larvae respectively when exposed to three plant extracts. This resistant may be due to the fact that $C x$. quinquefasciatus mosquitoes is found majorly in the wild, plants and animal interactions might have physiological affected it toxicity compare with $A n$. gambiae mosquito commonly found in human settlement in the study area (personal observation).

$\mathrm{LC}_{50}$ and $\mathrm{LC}_{90}$ increased as the mosquito developmental stage advanced. For larvae, pupae and adult mosquito, $\mathrm{LC}_{50}$ was more in An. gambiae compare with $C x$. quinquefasciatus. Also C. sumatrensis attained $\mathrm{LC}_{50}$ and $\mathrm{LC}_{90}$ at higher concentration than M. myristica. As larvicides, pupicides and adulticides the $\mathrm{LC}_{50} \mathrm{~S}$ and $\mathrm{LC}_{90} \mathrm{~S}$, after $24 \mathrm{~h}$ varied across plant extracts and mosquito species. On An. gambiae larvae, the $\mathrm{LC}_{50} \mathrm{~S}$ after $24 \mathrm{~h}$, varied from $86.95 \mathrm{mg} / \mathrm{L}$ (M. myristica) to $131.73 \mathrm{mg} / \mathrm{L}$ 
(C. sumatrensis). For $C x$. quinquefasciatus larvae, the $\mathrm{LC}_{50} \mathrm{~S}$ after $24 \mathrm{~h}$, varied from $103.83 \mathrm{mg} / \mathrm{L}$ (M. myristica) to 189.48 mg/L (C. sumatrensis). On An. gambiae larvae, the $\mathrm{LC}_{90} \mathrm{~S}$ after $24 \mathrm{~h}$, varied from $278.39 \mathrm{mg} / \mathrm{L}$ (M. myristica) to 131.73 $\mathrm{mg} / \mathrm{L} \quad$ (C. sumatrensis). For $C x$. quinquefasciatus larvae, the $\mathrm{LC}_{50} \mathrm{~S}$ after $24 \mathrm{~h}$, varied from $391.41 \mathrm{mg} / \mathrm{L}(M$. myristica) to $898.20 \mathrm{mg} / \mathrm{L} \quad(C$. sumatrensis). More concentrations were require to achieve $50 \%$ and $90 \%$ death of Cx. quinquefasciatus pupae.

Similar observation were reported by Tankeu et al. (2016) who worked on larvicidal activities of hydroethanolic extracts of three Cameroonian medicinal plants; Syzygium guineense, M. myristica and Zanthoxylum heitzii against Aedes albopictus. The seed extract of $M$. myristica exerted the best pupicidal activity among the two tested extracts with $\mathrm{LC}_{50}$ and $\mathrm{LC}_{90}$ values of $140.61 \mathrm{mg} / \mathrm{L}$ and $520.35 \mathrm{mg} / \mathrm{L}$ on An. gambiae, respectively, followed by leaf of C. sumatrensis with $\mathrm{LC}_{50}$ and $\mathrm{LC}_{90}$ values of $157.59 \mathrm{mg} / \mathrm{L}$ and $781.86 \mathrm{mg} / \mathrm{L}$ on An. gambiae, respectively. More concentrations were require to achieve $50 \%$ and $90 \%$ death of Cx. quinquefasciatus pupae. This ascribed to the report of Tankeu et al. (2016) who worked on larvicidal activities of three extracts against Aedes albopictus. On Adulticidal activity, seed of $M$. myristica exerted the best among the two tested plants with $\mathrm{LC}_{50}$ and $\mathrm{LC}_{90}$ values of $122.79 \mathrm{mg} / \mathrm{L}$ and $502.99 \mathrm{mg} / \mathrm{L}$ on $A n$. gambiae, respectively, followed by leaf of C. sumatrensis with $\mathrm{LC}_{50}$ and $\mathrm{LC}_{90}$ values of $215.05 \mathrm{mg} / \mathrm{L}$ and $981.25 \mathrm{mg} / \mathrm{L}$ on An.gambiae, respectively. More concentrations were require to achieve $50 \%$ and $90 \%$ death of CX. quinquefasciatus adults.

\section{Conclusion}

African nutmeg, M. myristica seeds and $C$. sumatrensis leaves extracts have shown significant larvicidal, pupicidal and adulticidal properties on
An. gambiae and $C x$. quinquefasciatus that causes human malaria and lymphatic filariasis. The two tested plants can be integrated into pest management programmes to combat human malaria and lymphatic filariasis vectors breeding site in Nigeria. The two plants are readily available in the trophic, ecofriendly, biodegradable and medicinal. I recommend formulation of $M$. myristica seeds which have the lowest $\mathrm{LC}_{50}$ and $\mathrm{LC}_{90}$ after $24 \mathrm{~h}$ for field evaluation in other to solve the problem of wild migration of vectors to human's settlement.

\section{Acknowledgments}

I thank Dr. F. A. Ologundudu of the Department of Biology, Federal University of Technology, Akure, Nigeria, for the identification of two plants evaluated in this study.

\section{Conflict of interest statement}

I declare that I have no conflict of interest.

\section{Reference}

Abbott, W. S. A method of computing the effectiveness of an insecticide. Journal of Economic Entomology, v. 18, p. 265-267, 1925.

Adedire, C. O. Use of nutmeg, Myristica fragans for the control of cowpea bruchid in storage, C. maculatus. Journal of Plant Diseases and Protection, v. 106, no. 6, p. 647-653, 2003

Adedire, C. 0.; Ajayi, T. S. Assessment of the insecticidal properties of some plant extracts as grain protection against the maize weevil, Sitophilus zeamais. Nigerian Journal of Entomology, v. 13, p. 93-101, 1996.

Adedire, C. O.; Lajide, L. Toxicity and oviposition deterrency of some plant extracts on cowpea storage bruchids, Callosobruchus maculatus. Journal of Plant Diseases and Protection, v. 106, p. 647-653, 1999.

Adedire, C. 0.; Obembe, 0. 0.; Akinkurolere, R. O.; Oduleye, O. Response of Callosobruchus maculatus (Coleoptera: Chysomelidae) to 
extracts of cashew kernels. Journal of Plant Diseases and Protection, v. 118, no. 2, p. 75-79, 2011.

Adewole, E.; Ajiboye, B.; O. Idris, 0. O.; Ojo, 0. A.; Onikan, A.; Ogunmodede, O. T.; Adewumi, D. F. Phytochemical, antimicrobial and Gc-Ms of African nutmeg (Monodora myristica). International Journal of Pharmaceutical Science Invention, v. 2, no. 5, p. 25-32, 2013.

Adjanohoun, J. E.; Aboubakar, N.; Dramane, K.; Ebot, M. E.; Ekpere, J. A.; Enoworock, E. G.; Focho, D.; Gbile, Z. O.; Kamanyi, A.; Kamsu, K. J.; Keita, A.; Mbenkum, T.; Mbi, C. N.; Mbiele, A. C.; Mbome, J. C.; Muberu, N. K.; Nancy, W. L.; Kongmeneck, B.; Satabie, B.; Sowora, A.; Tamze, V.; Wirmum, C. K. Traditional medicine and pharmacopoeia: Contribution to ethno botanical and floristic studies in Cameroon. Organization of African Unity, Scientific, Technical and Research Commission, 1996.

Afolabi, O. J.; Simon-Oke, I.; Adepeju E. O.; Oniya, M. O. Adulticidal and repellent activities of some botanical oils against malaria mosquito Anopheles gambiae (Diptera: Culicidae) Beni-Suef University Journal of Basic and Applied Sciences, v. 7, p. 134-138, 2018.

Akinkurolere, R. O.; Adedire, C. O.; Odeyemi, O. O.; Raji, J.; Owoeye, J. A. Bioefficacy of extracts of some indigenous Nigerian plants on the developmental stages of mosquito (Anopheles gambiae). Jordan Journal of Biological Science, v. 4, no. 4, p. 237-242, 2011.

Arivoli, S.; Ravindran, K. J.; Tennyson, S. Larvicidal efficacy of plant extracts against the malarial vector Anopheles stephensi Liston (Diptera: Culicidae). World Journal of Medical Sciences, v. 7, no. 2, p. 77-80, 2012.

Awosolu, 0.; Adesina, F.; Iweagu, M. Larvicidal effects of croton (Codiaeum variegatum) and Neem (Azadirachta indica) aqueous extract against Culex mosquito. International Journal of Mosquito Research, v. 5, no. 2, p. 15-18, 2018.

Beentje, H. J. Flora of Tropical East Africa. London: CRC Press, 2002. v. 1.

Chai, X.; Su, Y. F.; Gua, L P. Phenolic constituents from Conyza sumatrensis. Biochemical Systematics and Ecology, v. 36, p. 216-218, 2008.

Deans, S. G.; Svoboda K. P.; Gundidza, M.; Brechany, E.Y. Essential oil profiles of several temperate and tropical aromatic plants: their antimicrobial and antioxidant activities. Acta Horticulturae, v. 306, p. 229-232, 1992.

Emeasor, K. C.; Ogbuji, R. O.; Emosuire S. 0. Insecticidal activity of some seed powders against Callosobruchus maculatus on store product. Journal of Plant Disease and Protection, v. 112, p. 80-87, 2005.

Finney, D. J. Probit analysis. 2. ed. Cambridge: Cambridge University Press, 1971.

Gillies, M. T.; De Meillon, B. The Anophelinae of Africa South of the Sahara. South African Institute for Medicinal Research, v. 54, p. 1-343, 1968.

Ileke, K. D.; Ogungbite, O. C. Alstonia boonei De Wild oil extract in the management of mosquito (Anopheles gambiae), a vector of malaria disease. Journal of Coast Life Medicine, v. 3, no. 7, p. 557-563, 2015.

Ileke, K. D.; Oyeniyi, E. A.; Ogungbite, C. O.; Adesina, J. M. Nicotiana tabacum: A prospective mosquitocide in the management of Anopheles gambiae (Giles). International Journal of Mosquitoes Research, v. 2, no. 4, p. 19-23, 2015.

Ileke, K. D.; Adesina, J. M.; Obajulaye, E. 0. Synergetic effects of two botanicals entomocides as pest-protectants in maize grains. Journal of Biological Research, v. 89, no. 2, p. 33-39, 2016.

Kassir, J. T.; Mohsen, Z. H.; Mehdi, N. S. Toxic effect of limonene against Culex quinquefasciatus Say larvae and its interference with oviposition. Anzeiger Schadlingskunde Pflanze-Nschutz Umweltschutz, v. 62, no. 1, p. 19-21, 1989.

Kehail, M. A. A.; Bashir, $\quad$ N. H. H.; Abdelrahman, E. E.; Abdelrahim, A. M. Larvicidal activity of three plants powders and aqueous extracts on Anopheles and Culex mosquito larvae (Diptera: Culicidae). International Journal of Mosquito Research, v. 4, no. 4, p. 37-41, 2017.

Liu, J.; Luo, H. D.; Tan, W. Z.; Hu, L. First report of a leaf spot on Conyza sumatrensis caused by Phoma macrostoma in China. Plant Disease, v. 96, no. 1, p. 148, 2012.

Okorie, P. N.; Popoola, K. O. K.; Awobifa, O. M.; Ibrahim, K. T.; Ademowo, G. O. Species composition and temporal distribution of mosquito populations in Ibadan, Southwest Nigeria. Journal of Entomology and 
Zoology Studies, v. 2, no. 4, p. 164-169, 2014.

Okosun, 0. 0.; Adedire, C. O. Potency to cowpea seed bruchid, Callosobruchus maculatus of African nutmeg seed, Monodora myristica extracted with different solvents. Nigerian Journal of Entomology, v. 27, p. 89-95, 2010.

Okosun, 0. 0.; Adedire, C. O. Insecticidal Activities of African nutmeg solvent extracts agains cowpea seed bruchid, Callosobruchus maculatus (Fabricius) (Coleoptera: Bruchidae). Asian Journal of Agricultural Research, v. 11, no. 3, p. 86-92, 2017.

Pal, A.; Boniface, P. K.; Singh, M. HPLC-DAD fingerprinting of ethanol extracts from Conyza sumatrensis and Spathodea campanulata and their additive effect in Plasmodium berghei $\mathrm{K} 173$ infected mice. American Journal of Phytomedicine and Clinical Therapeutics, v. 2, no. 6, p. 660-669, 2014.

Sanei-Dehkordi, A.; Gholami, S.; Abai, M. R.; Sedaghat, M. M. Essential oil composition and larvicidal evaluation of Platycladus orientalis against two mosquito vectors, Anopheles stephensi and Culex pipiens. Journal of Arthropod-Borne Diseases, v. 12, no. 2, p. 101-107, 2018.

Sfara, V.; Zerba, E. N.; Alzogaray, R. A. Fumigant insecticidal activity and repellent effect of five essential oils and seven monoterpenes on first-instar nymphs of Rhodnius prolixus. Journal of Medical Entomology, v. 46, p. 511-515, 2009.

Shaalan, E. A. S.; Canyonb, D.; Younesc, M. W. F.; Wahaba H. A.; Mansoura, A. H. A review of botanical phytochemicals with mosquitocidal potential. Environment International, v. 31, p. 1149-1166, 2005.

Sukumar, K.; Perich, M. J.; Boobar, L. R. Botanical derivatives in mosquito control: a review. Journal of the American Mosquito Control Association, v. 7, no. 2, p. 210-237, 1991.

Tankeu, N. F.; Biapa, N. P.; Pieme, C. A.; Moukette, M. B.; Nanfack, P.; Ngogang, Y. J.
Larvicidal activities of hydro-ethanolic extracts of three Cameroonian medicinal plants against Aedes albopictus. Asian Pacific Journal of Tropical Biomedicine, v. 6, no. 11, p. 931-936, 2016.

Udo, I. O. Potentials of Zanthoxylum xanthoxyloides (LAM.) for the control of stored product insect pests. Journal Stored Products and Postharvest Research, v. 2, no. 3, p. 40-44, 2011.

Vatandoost, H.; Rustaie, A.; Talaeian, Z.; Abai, M. R.; Moradkhani, F.; Vazirian, M. Hadjiakhoondi, A.; Shams-Ardekani, M. R.; Khanavi, M. Larvicidal activity of Bunium persicum essential oil and extract against malaria vector, Anopheles stephensi. Journal of Arthropod-Borne Diseases, v. 12, no. 1, p. 85-93, 2018.

Vincent, P. K. T.; Denis, Z.; Moses, N. N. The antimalarial potential of medicinal plants used for the treatment of malaria in Cameroonian folk medicine. African Journal of Traditional Complement and Alternative Medicine, v. 5, p. 302-321, 2008. Vindhya, K.; Sampath, Kumara, K. K.; Neelambika, H. S.; Leelavathi, S. Preliminary phytochemical screening of Gardenia latifolia Ait. and Gardenia gummifera Linn. Research Journal of Pharmaceutical, Biological and Chemical Sciences, v. 5, p. 527-532, 2014.

Weiss, E. A. Spice crops. Oxon: CABI Publishing. 2002.

WHO. Guidelines for testing mosquito adulticides for indoor residual spraying and treatment of mosquito nets. WHO Bulletin, v. 3, p. 27-39, 2006.

WHO - World Health Organization. Guidelines for efficacy testing of mosquito repellents for human skin. WHO Bulletin, v. 4, p.1-28, 2009.

WHO - World Health Organization. Larval source management: a supplementary measure for malaria vector control - An operational manual. Geneva: WHO, 2013.

WHO - World Health Organization. World malaria report. Geneva, Switzerland: WHO, 2016. 